\title{
The effects of energy source and tryptophan on the rate of protein synthesis and on hormones of the entero-insular axis in the piglet
}

\author{
BY A. A. PONTER ${ }^{1, *}$, N. O. CORTAMIRA ${ }^{2, \dagger}$, B. SÈVE ${ }^{2}$, D. N. SALTER AND \\ L. M. MORGAN ${ }^{3}$ \\ ${ }^{1}$ Institute of Grassland and Environmental Research, Church Lane, Shinfield, Reading, RG2 $9 A Q$ \\ ${ }^{2}$ I.N.R.A., Station de Recherches Porcines, Saint-Gilles, 35590 L'Hermitage, France \\ ${ }^{3}$ School of Biological Sciences, University of Surrey, Guildford, Surrey, GU2 $5 \mathrm{XH}$
}

(Received 26 October 1992 - Revised 12 August 1993 - Accepted 2 September 1993)

\begin{abstract}
The present experiment was designed to study the influence of dietary energy source (fat or carbohydrate) and tryptophan (TRP) on protein synthesis and plasma insulin concentrations in the piglet. Six dietary regimens, based on either a high-fat (F) or a high-carbohydrate (C) diet with three levels of TRP (deficient, 1 ; adequate, 2 ; excess, 3$)$, were used. Fractional protein synthesis rate $\left(k_{s} ; \%\right.$ per d) was measured in the liver, Longissimus dorsi (LD), Semitendinosus (ST), skin, femur, brain, pancreas, stomach, mucosa of the duodenum and jejunum, and the whole body, using a 'flooding dose' of ${ }^{3} \mathrm{H}$-phenylalanine. Mean integrated insulin, gastric inhibitory polypeptide (GIP) and glucose concentrations were higher after the $\mathrm{C}$ diets compared with the $\mathrm{F}$ diets, TRP supplementation globally augmented $k_{s}$ linearly in the liver, ST, skin and whole body, while it had quadratic effects in the LD $\left(k_{s}\right.$ highest in the TRP-adequate diet groups) and jejunal mucosa ( $k_{s}$ lowest in the TRP-adequate diet groups). Pancreatic $k_{s}$ was increased by TRP addition up to a plateau. $k_{s}$ was highest after the $F$ diets in the digestive tissues while in the skin and LD $k_{s}$ was highest after the $C$ diets. Fasting concentrations of gluconeogenic amino acids were lower (and urea higher) with the $F$ than the $C$ diets, suggesting their use as precursors for glucose synthesis. In conclusion, we have confirmed the depressive effects of TRP deficiency on $\boldsymbol{k}_{\mathrm{s}}$, RNA activity and growth. We could not establish a relationship between plasma insulin and muscle $k_{s}$. This may be related to the way in which we manipulated plasma insulin concentrations.
\end{abstract}

Protein synthesis: Insulin: Tryptophan: Piglets

There have been few studies comparing the dietary effects of energy source on rate of protein synthesis; however, Reeds et al. (1981) showed that both fat and carbohydrate were equally effective in increasing whole-body protein synthesis, decreasing protein degradation and reducing amino acid catabolism. They also showed that the time course of this effect was different and that it may be related to the balance between insulin and cortisol (Reeds et al. 1987). Garlick \& Lobley (1987) showed in rats that intravenous infusion of high levels of insulin, glucose and amino acids stimulates muscle protein synthesis and that the concentrations of insulin and glucose infused were significantly correlated with the fractional rate of protein synthesis $\left(k_{s}\right)$. However, perfusion of low levels of insulin did not simulate the effect of feeding on $k_{s}$. Therefore, insulin is not the only mediator of the response of $k_{s}$ to a meal.

Studies of protein metabolism in individual muscles and the liver have shown that protein synthesis can be influenced by dietary tryptophan (TRP) level (Cortamira et al.

* Present address: Ecole Nationale Vétérinaire d'Alfort, Nutrition et Alimentation, 7 Avenue du Général-deGaulle, 94704 Maisons-Alfort, France.

$\dagger$ Present address: I.N.T.A., Porcine Section, E.E.A., 2700 Pergamino, Argentina. 
$1991 \mathrm{a}$ ). The action of TRP could be related to an increase in the level of RNA (Vesely \& Cihak, 1970), although it could equally result from a stimulation of ribosome aggregation (Sidransky et al. 1971) corresponding to an augmentation in ribosome activity. An alteration in ribosome activity could be linked to the action of hormones, for example insulin, on $k_{s}$ (Jefferson, 1980).

Recently, Cortamira et al. (1991 a) showed that the concentrations of insulin and glucose in the plasma were higher after a TRP-supplemented diet than after a TRP-deficient diet. They proposed that the influence of TRP on protein synthesis may be related to an increase in plasma insulin concentration. One of the main candidates for gut-mediated insulin release is gastric inhibitory polypeptide (GIP; Brown, 1974). GIP concentrations are augmented by the absorption of carbohydrates (Sykes et al. 1980), fatty acids (Brown, 1974) and amino acid mixtures (Thomas et al. 1978). In addition to this, individual amino acids also augment the concentrations of GIP, for example L-TRP in rats (Tsiolakis \& Marks, 1984) and in man (McPhate, 1986).

The present experiment was designed to investigate whether the rate of protein synthesis is influenced by dietary energy source and TRP level and whether there is an association between plasma insulin concentration and the rate of protein synthesis in individual tissues. Plasma insulin concentrations have been shown to be affected by the fat:carbohydrate ratio in the diet (Ponter et al. 1991a) and by dietary TRP level (Cortamira et al. 1991 a). A preliminary report of these results has been made (Cortamira et al. 1991 b).

\section{MATERIALS AND METHODS}

\section{Animals and diets}

Forty-two Large White male and female piglets (seven litters of six pigs) were used, taken from the herd of INRA-St. Gilles. The piglets were weaned at $10 \mathrm{~d}$ of age and kept in individual adjoining metabolism cages on wire floors throughout the experimental period at an environmental temperature of $30^{\circ}$. Two semi-purified diets were formulated to be either high in carbohydrate (C1) or high in fat (F1; Table 1) and deficient in tryptophan. The tryptophan: digestible energy ratio was maintained at the same level in the two basal diets. Graded amounts of purified L-tryptophan were added to produce two further diets from each of the basal diets. Therefore, in total six dietary regimens were produced corresponding to deficient $(\mathrm{Cl}, \mathrm{F} 1 ; 113 \mathrm{mg} \mathrm{TRP} / \mathrm{MJ}$ digestible energy (DE)), adequate (C2, F2; $160 \mathrm{mg}$ TRP/MJ DE) and excess (C3, F3; $212 \mathrm{mg}$ TRP/MJ DE) amounts with respect to the piglets' requirements for tryptophan (Institut National de la Recherche Agronomique, 1989). Within each litter the six dietary treatments were represented.

\section{Feeding methods}

The feeding scale was designed so that all piglets received the same amount of digestible energy in relation to metabolic weight $\left(\mathrm{kg}^{0 \cdot 75}\right)$. The feeding scale is shown in Table 2 . The diets were infused directly into the stomach through an indwelling gastric catheter. The diets were mixed $(1: 3 ; \mathrm{w} / \mathrm{w})$ with water $\left(30^{\circ}\right)$ and continuously agitated whilst being infused by syringe. The rate of infusion was approximately $60 \mathrm{ml} / \mathrm{min}$ with $3 \mathrm{~min}$ between each $60 \mathrm{ml}$. The daily allowance was divided into three portions $(45 \%, 20 \%$ and $35 \%)$ and given at $08.00,11.00$ and 16.00 hours respectively. Water was available $a d$ lib. throughout the experimental period.

Two surgical operations were performed under general anaesthesia and aseptic conditions to place a gastric tube and jugular catheter (at 10 and $16 \mathrm{~d}$ of age respectively; Cortamira et al. 1991 a). The patency of the jugular catheter was maintained by flushing with heparinized saline $(9 \mathrm{~g} \mathrm{NaCl} / 1$, containing 10 units of heparin $/ \mathrm{ml})$.

At $22 \mathrm{~d}$ of age blood samples were taken from the jugular vein, after the intragastric 
Table 1. Composition $(\mathrm{g} / \mathrm{kg})$ of the basal diets: high-carbohydrate $(\mathrm{Cl})$ and high-fat $(\mathrm{Fl})$

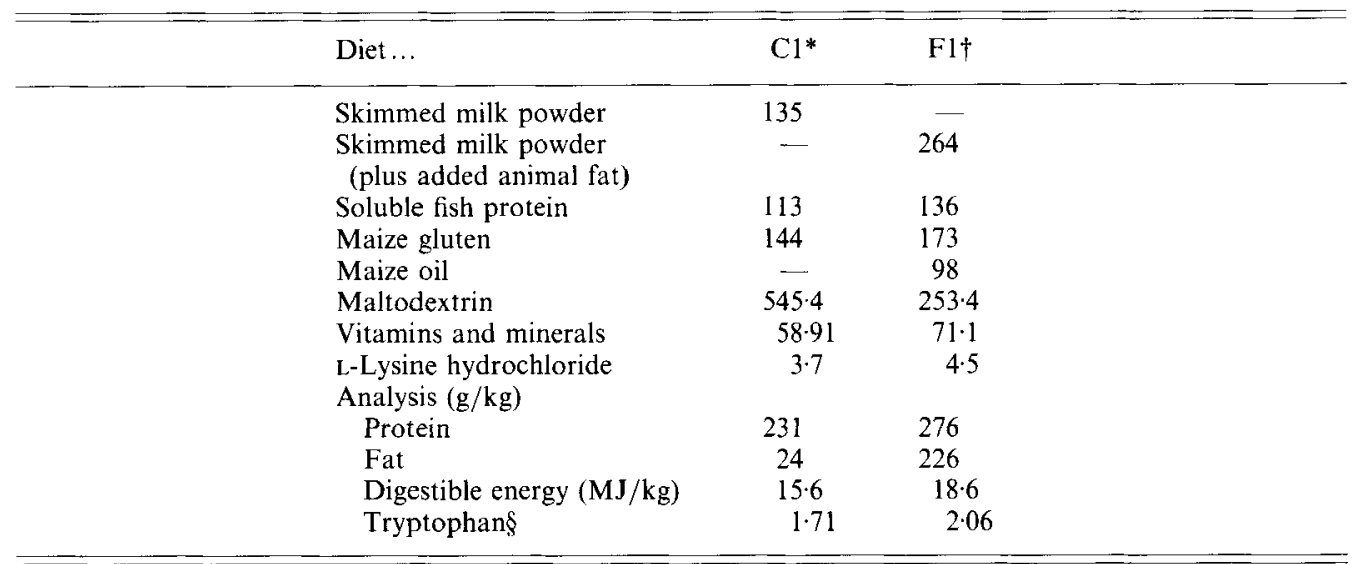

* Diets $\mathrm{C} 2$ and $\mathrm{C} 3$ were obtained by the addition of 0.8 and $1.6 \mathrm{~g} \mathrm{~L}$-tryptophan $/ \mathrm{kg}$ to the basal diet $(\mathrm{C} 1)$ respectively.

$\dagger$ Diets F2 and F3 were obtained by the addition of 0.94 and $1.89 \mathrm{~g} \mathrm{L-tryptophan} / \mathrm{kg}$ to the basal diet (F1) respectively.

$\S$ Calculated from tables of feed composition (Institut National de la Recherche Agronomique, 1989).

Table 2. Daily feed allowance $\left(\mathrm{g} / \mathrm{kg}^{0.75}\right)$ of the high-carbohydrate $(C)$ and high-fat $(F)$ diets for piglets $10-27 d \S$

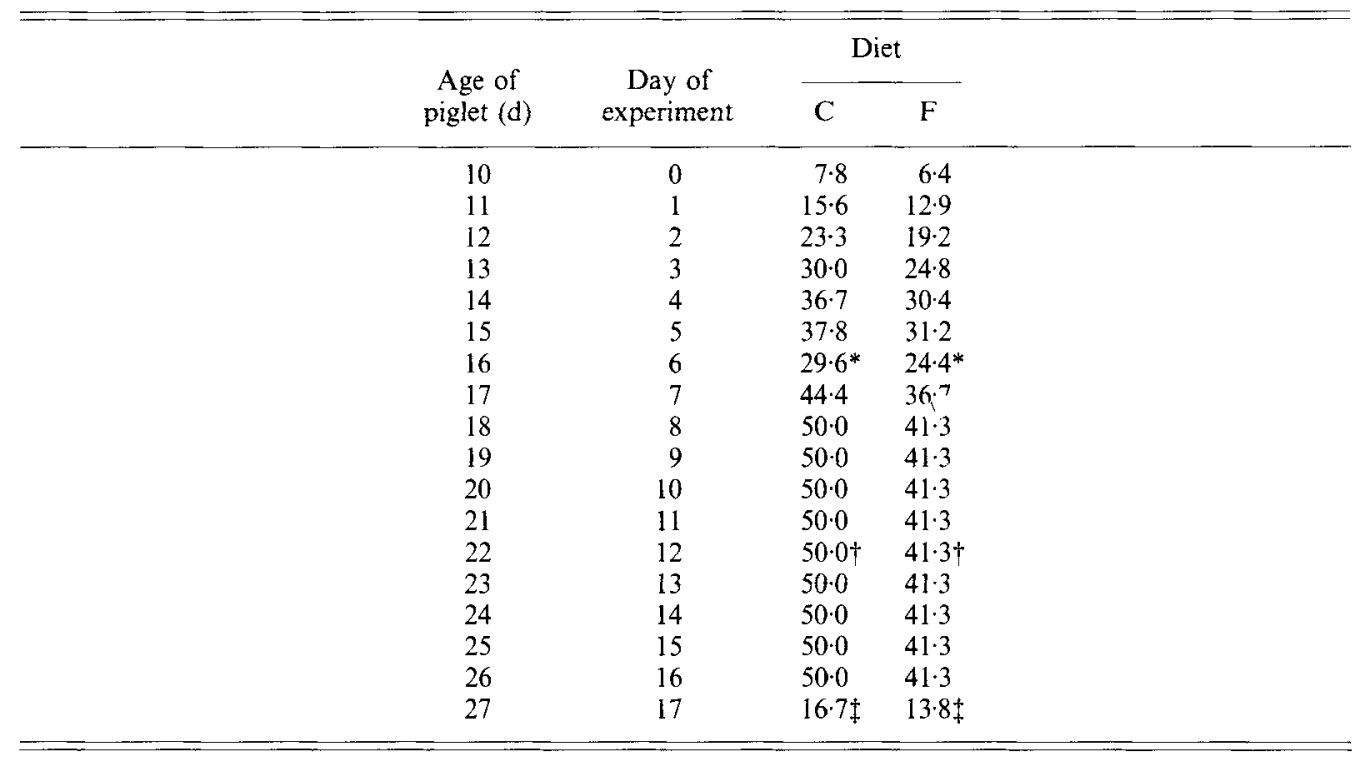

* Day of surgical operation to place jugular catheter; the morning meal was not given.

$\uparrow$ One third of the daily allowance of the accustomed diet was given at 08.00 hours and blood samples were taken from the jugular catheter.

$\ddagger$ One third of the daily allowance of the accustomed diet was given $2 \mathrm{~h}$ before the 'flooding' injection of phenylalanine.

$\S$ For details of diets and feeding methods see Table 1 and pp. 662-664. 
infusion of one-third of the daily allowance of the accustomed diet, at $0,10,20,30,40,60$ and $120 \mathrm{~min}$ in relation to the infusion. Blood samples were immediately centrifuged at $2000 \mathrm{~g}$ for $15 \mathrm{~min}$ at a temperature of $4^{\circ}$ after collection into ice-cooled tubes which contained $50 \mathrm{IU}$ heparin and $1000 \mathrm{IU}$ aprotinin (Iniprol; Laboratoire Choay, Paris, France) $/ \mathrm{ml}$ blood. Plasma was removed and stored at $-20^{\circ}$. Blood samples were also taken after glucose load (Ponter et al. 1991 b).

\section{Experimental procedure at slaughter}

At $27 \mathrm{~d}$ of age, overnight fasted piglets were given the morning meal at time $t 0 \mathrm{~min}$, and at time $t 120 \mathrm{~min}$ a 'flooding dose' of phenylalanine was given via the jugular catheter. A blood sample was taken just before the meal to measure plasma amino acid and urea concentrations. The flooding injection consisted of $5.5 \mathrm{ml} / \mathrm{kg}$ live weight of a $150 \mathrm{mmol}$ solution of L-phenylalanine combined with $600 \mathrm{kBq} / \mathrm{ml}$ of $\mathrm{L}-\left(4-{ }^{3} \mathrm{H}\right)$ phenylalanine (DOSITEK, Orsay, France). At time $t 132 \mathrm{~min}$ the piglets were anaesthetized and slaughtered by cutting the carotid arteries. Samples of Longissimus dorsi (LD), Semitendinosus (ST), skin, femur, brain, liver, pancreas, stomach and the mucosa from the duodenum and jejunum were collected and immediately deep-frozen in liquid $\mathrm{N}_{2}$. The time $(T)$ that had elapsed between the injection of phenylalanine and freezing was noted. Mucosa samples were taken from the first $500 \mathrm{~mm}$ and second $500 \mathrm{~mm}$ immediately posterior to the stomach (designated duodenum and jejunum respectively). The small intestine was separated from the mesentery and rinsed of digesta. The mucosa was gently scraped free from the other layers with a knife on an ice-cooled metal surface. After tissue sampling the whole empty body, without blood, was also frozen in liquid $\mathrm{N}_{2}$. It was later minced and sampled after mechanical homogenization, in order to determine protein synthesis in the whole body.

\section{Analyses}

Plasma venous immunoreactive insulin and GIP were measured using double-antibody techniques (Guildhay Antisera, Guildford, Surrey; Morgan et al. 1978). The sensitivities of the assays were $3 \mathrm{mU} / 1$ and $125 \mathrm{pg} / \mathrm{ml}$ respectively (Ponter et al. 1991 a). Plasma glucose concentrations were measured using a glucose oxidase $(E C$ 1.1.3.4) kit (Baker Instruments, Sanford, ME, USA) on a fully automated clinical analyser (Encore Clinical Chemistry System; Baker Instruments, Sanford, ME, USA). Amino acids were analysed in plasma deproteinized with one volume of $0.236 \mathrm{M}$-sulfosalicylic acid combined with an internal standard ( $\mathrm{L}-\alpha$-amino- $\beta$-guanidinopropionic acid). The supernatant was adjusted to pH 2.2 with $100 \mu 10.4 \mathrm{M}$-citric acid adjusted to $\mathrm{pH} 5$ with $4 \mathrm{M}-\mathrm{LiOH}$. Chromatographic separation of the amino acids was performed on a Biotronik LC 5001 analyser. A special run was used to analyse TRP; under these conditions total plasma TRP was measured (Sève et al. 1991).

The diets were analysed for protein and fat. $\mathrm{N}$ was determined by Kjeldahl digestion followed by colorimetric assay of the digest using a continuous, segmented flow colorimetric analyser (ChemLab, Hornchurch, Essex); crude protein is given as $\mathrm{N} \times 6.25$. The fat content was determined by Soxhlet extraction with light petroleum (b.p. $40-60^{\circ}$ ).

The tissue samples were analysed for protein, RNA and the specific activities of phenylalanine in the free pool (SA) and in the tissue protein (SB) as described by Cortamira et al. $(1991 a)$ and $k_{s}(\%$ per d) was calculated from 100\% (SB/SA)/T (Cortamira et al. $1991 a)$.

\section{Statistical analysis}

The mean integrated areas under the curve for GIP, insulin and glucose during the sampling period $(0-120 \mathrm{~min})$ were calculated using a maximum likelihood programme 
(MLP; Ross, 1980). Statistical analysis was performed using the general linear model procedure of SAS (Statistical Analysis Systems, 1989). Basal concentrations of glucose were analysed for an effect of regimen, with litters treated as blocks. The effects of regimen on the integrated concentrations of GIP, insulin and glucose, on the protein synthesis data and the plasma amino acid and urea concentrations were analysed using a randomized-block design analysis of variance. The model included the effects of litter, energy source, TRP and the TRP $\times$ energy source interaction. The effects of TRP and TRP $\times$ energy source interaction were partitioned into linear and quadratic effects using the contrast statement of SAS.

\section{RESULTS}

\section{Growth data}

Growth rate was significantly improved by the addition of TRP to the basal diets $(P=$ $0.006)$ and the replacement of the energy from fat by that from carbohydrate $(P=0.011)$. There was also an interaction between dietary energy and TRP level showing that the beneficial effect of TRP addition was obtained only with high-fat diets $(P=0.05$; Fig. 1$)$.

\section{Blood measurements}

Fasting insulin and GIP concentrations were below the sensitivity limits of the respective assays and fasting glucose concentration was unaffected by dietary treatment. The mean integrated (0-120 $\mathrm{min})$ insulin, GIP and glucose concentrations were higher in response to the $\mathrm{C}$ diets compared with the $\mathrm{F}$ diets $(P=0.0001,0.008$ and 0.0008 respectively). There was also a trend for TRP to have a quadratic effect on plasma insulin $(P=0.07)$, plasma insulin being higher in response to the low and high TRP diets compared with the adequate diets (Table 3).

The mean plasma concentrations of the gluconeogenic amino acids (alanine, glycine, serine, threonine, cystine, glutamate, glutamine, histidine, proline, arginine, methionine, valine, aspartate and asparagine) were significantly higher before the meal in pigs receiving the $\mathrm{C}$ diets compared with pigs receiving the $\mathrm{F}$ diets $(P=0 \cdot 015)$. There was a strong trend to a similar effect on gluconeogenic/ketogenic amino acids (isoleucine, tyrosine and phenylalanine; $P=0.063$ ). However, ketogenic amino acids (leucine and lysine) were not influenced by dietary treatment. Fasting plasma urea concentrations were higher in pigs receiving the $\mathrm{F}$ diets compared with the $\mathrm{C}$ diets $(P=0.064$; Table 4$)$.

Fasting plasma TRP levels were affected linearly by the addition of TRP to the basal diet $(P=0.0001)$ and were affected by an interaction between energy source and TRP level $(P$ $=0.002$. TRP-deficiency induced lower plasma TRP concentrations with the C compared with the $F$ diets, while there was no difference between the energy sources when TRP was added (Fig. 2).

\section{Protein synthesis data}

Adaptation to the $\mathrm{F}$ diets caused the rate of protein synthesis to be augmented in the stomach, pancreas and the mucosa from the duodenum and the jejunum when compared with the $C$ diets (Table 5). Increasing the TRP level caused a linear increase $(P=0.028)$ in pancreatic protein synthetic rate and there was a trend for a quadratic effect $(P=0 \cdot 10)$. This indicates a positively curved response to the addition of TRP. Generally TRP supplementation to the diet had a negative linear effect on the rate of protein synthesis in the duodenal mucosa $(P=0.031)$ and a quadratic effect in the jejunal mucosa $(P=0.034)$, $k_{s}$ being lowest in the TRP-adequate diets. The rate of protein synthesis in the duodenal mucosa was affected by a linear interaction between energy source and TRP level $(P=$ 0.033 ) where the addition of TRP to F diets decreased $k_{s}$ while there was no effect with $\mathrm{C}$ diets. 


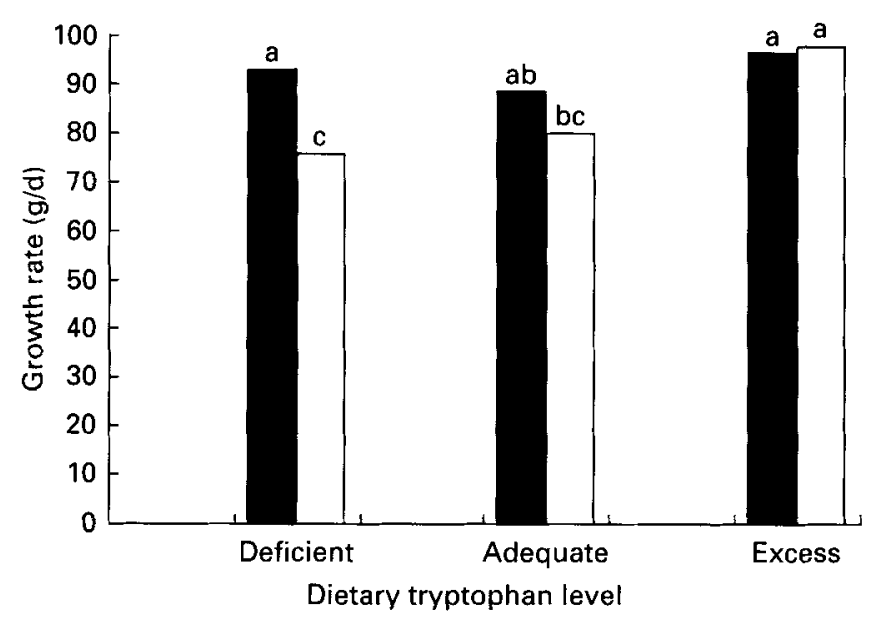

Fig. 1. Effect of energy source (E) and tryptophan level $(\mathrm{T})$ on the mean daily live-weight gain $(\mathrm{g} / \mathrm{d})$ of piglets. (口), carbohydrate-rich diets; $(\square)$, fat-rich diets. For details of diets and treatments, see Table 1 and p. 662 . Columns bearing different letters are significantly different: $\mathrm{E}, P=0.011 ; \mathrm{T}, P=0.006 ; \mathrm{E} \times \mathrm{T}, P=0.05$; residual standard deviation $9 \cdot 8(30 \mathrm{df})$.

Table 3. Effect of dietary energy source and tryptophan level on the mean integrated $\$$ plasma insulin, gastric inhibitory polypeptide (GIP) and glucose concentrations of piglets§

\begin{tabular}{|c|c|c|c|c|c|c|c|c|}
\hline \multirow[b]{2}{*}{$\begin{array}{l}\text { Diet... } \\
n \ldots\end{array}$} & \multirow[b]{2}{*}{$\begin{array}{c}\mathrm{C} 1 \\
7\end{array}$} & \multirow[b]{2}{*}{$\begin{array}{c}\mathrm{C} 2 \\
7\end{array}$} & \multirow[b]{2}{*}{$\begin{array}{c}\text { C3 } \\
7\end{array}$} & \multirow[b]{2}{*}{$\begin{array}{c}\mathrm{F} 1 \\
7\end{array}$} & \multirow[b]{2}{*}{$\begin{array}{c}F 2 \\
6\end{array}$} & \multirow[b]{2}{*}{$\begin{array}{c}F 3 \\
6\end{array}$} & \multicolumn{2}{|c|}{$\begin{array}{c}\text { Statistical } \\
\text { significance }\end{array}$} \\
\hline & & & & & & & RSD & Effects \\
\hline Insulin $(\mathrm{mU} / \mathrm{I})$ & $197 \cdot 7$ & $133 \cdot 9$ & $184 \cdot 0$ & $95 \cdot 9$ & $89 \cdot 2$ & 101.9 & $54 \cdot 4$ & $\begin{array}{c}\mathrm{E}^{* * *} \text { quad } \\
\mathrm{T} \dagger \text { qua }\end{array}$ \\
\hline GIP (ng/l) & 5612 & 5020 & 6210 & 4208 & 4240 & 4649 & 1395 & $\mathrm{E}^{* *}$ \\
\hline Glucose $(\mathrm{mmol} / 1)$ & $8 \cdot 88$ & 8.36 & $8 \cdot 79$ & $7 \cdot 41$ & 6.69 & 6.50 & 1.53 & $\mathrm{E}^{* * *}$ \\
\hline
\end{tabular}

C, high-carbohydrate diets; F, high-fat diets; 1, tryptophan-deficient diet; 2, tryptophan-adequate diet; 3 , tryptophan-excess diet. Statistical effects: E, energy source; T, tryptophan level; quad, quadratic effect; RSD, residual standard deviation; $\dagger P=0.07 ; * * P<0.01 ; * * * P<0.001$.

$\ddagger$ Integration performed by a maximum likelihood programme (Ross, 1980). Values obtained by dividing the area under the curve by $120 \mathrm{~min}$.

$\S$ For details of diets and procedures see Table 1 and pp. 662-665.

Liver $k_{s}$ was linearly augmented $(P=0.002)$ by the addition of TRP to a TRP-deficient diet rich in carbohydrate but not fat. This was indicated by the trend to a quadratic interaction between energy source and TRP level $(P=0.082)$. In the carbohydrate-rich diets the addition of TRP linearly augmented $k_{s}$, while in the fat-rich diets there was a quadratic effect with TRP addition ( $k_{s}$ being highest in TRP-adequate diet group). There was a trend $(P=0.08)$ for the addition of TRP to increase $k_{s}$ linearly in brain tissue. The rate of protein synthesis in the skin was increased linearly by the addition of TRP $(P=$ $0.005)$ and $k_{s}$ was significantly higher with the $\mathrm{C}$ diets compared with the $\mathrm{F}$ diets $(P=$ $0.003)$. Energy and TRP level had an interactive effect on $k_{s}$ in the femur $(P=0.036)$, TRP addition to the deficient diets only increased $k_{s}$ with the $\mathrm{F}$ diets. The $k_{s}$ of the LD was affected quadratically by the addition of TRP $\left(P=0.05 ; k_{\varepsilon}\right.$ highest in TRP group 2$)$, while in the ST it was linearly increased by TRP $(P=0.007)$. There was a trend for $k_{s}$ to be 
Table 4. Effect of dietary energy source and tryptophan level on the mean fasting plasma concentrations of gluconeogenic, gluconeogenic/ketogenic and ketogenic amino acids $\ddagger$ and urea $(\mathrm{mmol} / \mathrm{l})$ in piglets§

\begin{tabular}{|c|c|c|c|c|c|c|c|c|}
\hline \multirow[b]{2}{*}{$\begin{array}{l}\text { Diet... } \\
n \ldots\end{array}$} & \multirow[b]{2}{*}{$\begin{array}{c}\mathrm{Cl} \\
7\end{array}$} & \multirow[b]{2}{*}{$\begin{array}{c}\mathrm{C} 2 \\
7\end{array}$} & \multirow[b]{2}{*}{$\begin{array}{c}\mathrm{C} 3 \\
7\end{array}$} & \multirow[b]{2}{*}{$\begin{array}{c}\text { F1 } \\
7\end{array}$} & \multirow[b]{2}{*}{$\begin{array}{c}F 2 \\
6\end{array}$} & \multirow[b]{2}{*}{$\begin{array}{c}\text { F3 } \\
6\end{array}$} & \multicolumn{2}{|c|}{$\begin{array}{c}\text { Statistical } \\
\text { significance }\end{array}$} \\
\hline & & & & & & & RSD & Effects \\
\hline $\begin{array}{l}\text { Gluconeogenic } \\
\text { amino acids }\end{array}$ & 2.94 & $2 \cdot 84$ & 2.95 & $2 \cdot 34$ & $2 \cdot 23$ & $2 \cdot 41$ & 0.63 & $\mathrm{E}^{*}$ \\
\hline $\begin{array}{l}\text { Gluconeogenic/ } \\
\text { ketogenic amino } \\
\text { acids }\end{array}$ & 0.20 & 0.19 & 0.22 & $0 \cdot 19$ & 0.14 & 0.18 & 0.05 & $\mathrm{E}_{\dagger}^{\dagger}$ \\
\hline $\begin{array}{l}\text { Ketogenic amino } \\
\text { acids }\end{array}$ & 0.20 & $0 \cdot 20$ & 0.25 & 0.22 & $0 \cdot 18$ & 0.21 & $0-06$ & NS \\
\hline Urea & $2 \cdot 38$ & $2 \cdot 40$ & 2.55 & $3 \cdot 26$ & $2 \cdot 68$ & $2 \cdot 56$ & 0.56 & E† \\
\hline
\end{tabular}

$\mathrm{C}$, high-carbohydrate diets; F, high-fat diets; 1, tryptophan-deficient diet; 2, tryptophan-adequate diet; 3 , tryptophan-excess diet. Statistical effects: E, energy source; RSD, residual standard deviation; NS, not significant; $\uparrow P=0.06 ; * P<0.05$.

\$For details of gluconeogenic, gluconeogenic/ketogenic and ketogenic amino acids see p. 665 .

$\S$ For details of diets and procedures see Table 1 and pp. 662-665.

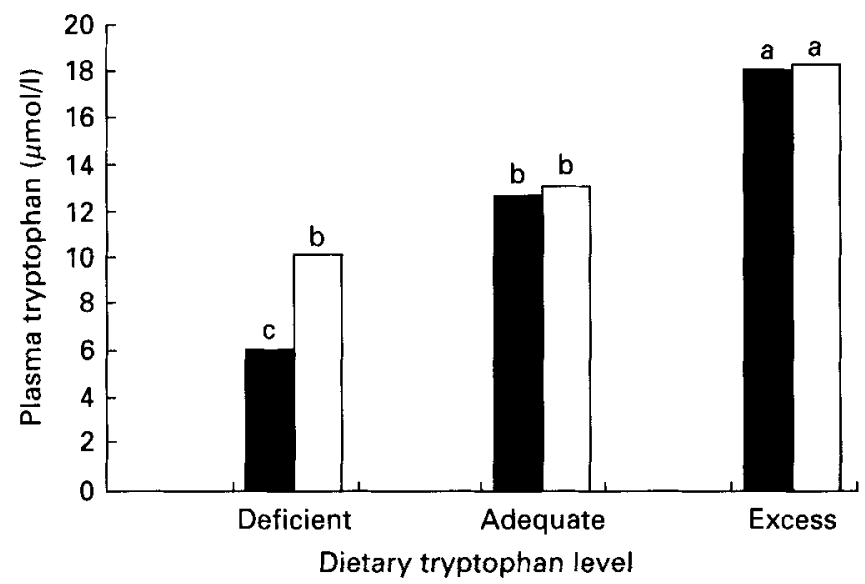

Fig. 2. Effect of energy source (E) and tryptophan level (T) on the mean plasma concentration of tryptophan $(\mu \mathrm{mol} / 1)$ before the accustomed meal. ( $\square)$, carbohydrate-rich diets; $(\square)$, fat-rich diets. For details of diets and treatments, see Table 1 and pp. 662-664. Columns bearing different letters are significantly different: $\mathrm{E}, P=0 \cdot 003$; $\mathrm{T}, P=0.0001 ; \mathrm{E} \times \mathrm{T}, P=0.002$, residual standard deviation 1.37 ( $24 \mathrm{df})$.

enhanced with the replacement of fat by carbohydrate in the LD $(P=0 \cdot 064)$. Whole body $k_{\mathrm{s}}$ was linearly increased by the addition of TRP $(P=0.01$; Table 5$)$, while energy source had no effect.

\section{Tissue RNA (RNA capacity)}

The concentrations of RNA in the femur, liver, whole body, pancreas, stomach and duodenal mucosa were unaffected by dietary treatment (results not shown). Substitution of fat for carbohydrate in the diet caused an increase in the concentration of RNA in the jejunal mucosa $(P=0.014)$ and there was also a linear decrease in the RNA content of this 
Table 5. Effect of dietary energy source and tryptophan level on the mean fractional rates of protein synthesis $(\%$ per $d)$ in various organs of the piglet $\ddagger$

\begin{tabular}{|c|c|c|c|c|c|c|c|c|}
\hline \multirow{2}{*}{$\begin{array}{l}\text { Diet... } \\
n \ldots\end{array}$} & \multirow{2}{*}{$\begin{array}{c}\mathrm{Cl} \\
7\end{array}$} & \multirow{2}{*}{$\begin{array}{c}\mathrm{C} 2 \\
7\end{array}$} & \multirow{2}{*}{$\begin{array}{c}\mathrm{C} 3 \\
7\end{array}$} & \multirow{2}{*}{$\begin{array}{c}\text { F1 } \\
7\end{array}$} & \multirow{2}{*}{$\begin{array}{c}F 2 \\
6\end{array}$} & \multirow{2}{*}{$\begin{array}{c}\mathrm{F} 3 \\
6\end{array}$} & \multicolumn{2}{|r|}{ Statistical significance } \\
\hline & & & & & & & RSD & Effects \\
\hline Pancreas & $55 \cdot 5$ & $76 \cdot 2$ & $77 \cdot 2$ & 83.5 & 99.9 & $94 \cdot 1$ & $18 \cdot 1$ & $\mathrm{~T}^{*}$ lin and $\dagger$ quad, $\mathrm{E}^{* * *}$ \\
\hline Stomach & $36 \cdot 0$ & $37 \cdot 0$ & $38 \cdot 1$ & $42 \cdot 3$ & $39 \cdot 1$ & $45 \cdot 1$ & $6 \cdot 4$ & $\mathrm{E}^{*}$ \\
\hline Duodenal mucosa & $58 \cdot 9$ & $59 \cdot 4$ & $58 \cdot 8$ & $78 \cdot 0$ & 63.7 & $59 \cdot 9$ & $10 \cdot 4$ & $\begin{array}{l}\mathrm{T}^{*} \operatorname{lin}, \mathrm{E}^{*} \\
\mathrm{E} \times \mathrm{T}^{*} \operatorname{lin}\end{array}$ \\
\hline Jejunal mucosa & $55 \cdot 9$ & 46.5 & $51 \cdot 4$ & $74 \cdot 0$ & $62 \cdot 5$ & $70 \cdot 7$ & $11 \cdot 2$ & $\mathrm{~T}^{*}$ quad, $\mathrm{E}^{* * *}$ \\
\hline Liver & 73.5 & $78 \cdot 2$ & $92 \cdot 3$ & $77 \cdot 4$ & 87.9 & 83.8 & $9 \cdot 7$ & $\mathrm{~T}^{* * *} \operatorname{lin}, \mathrm{E} \times \mathrm{T}^{\dagger}$ quad \\
\hline Skin & $12 \cdot 8$ & 14.9 & $15 \cdot 2$ & $11 \cdot 6$ & $11 \cdot 7$ & $13 \cdot 7$ & 1.9 & $T^{* *} \operatorname{lin}, E^{* *}$ \\
\hline Femur & $41 \cdot 9$ & $43 \cdot 5$ & $40 \cdot 3$ & $41 \cdot 1$ & 46.4 & $49 \cdot 6$ & $5 \cdot 3$ & $E \times T^{*}$ quad \\
\hline Longissimus dorsi & $10 \cdot 2$ & 11.5 & 9.5 & 7.9 & $10 \cdot 0$ & $9 \cdot 1$ & $2 \cdot 3$ & $\mathrm{~T}^{*}$ quad, $\mathrm{E} \dagger$ \\
\hline Semitendinosus & 7.9 & $9 \cdot 2$ & 8.8 & $6 \cdot 4$ & $8 \cdot 4$ & 8.9 & $1 \cdot 5$ & $\mathrm{~T}^{* *} \operatorname{lin}$ \\
\hline Whole body & 14.9 & $15 \cdot 7$ & 16.7 & $13 \cdot 4$ & $16 \cdot 8$ & $16 \cdot 5$ & $2 \cdot 2$ & $\mathrm{~T}^{* *} \operatorname{lin}$ \\
\hline
\end{tabular}

C, high-carbohydrate diets; F, high-fat diets; 1, tryptophan-deficient diet; 2, tryptophan-adequate diet; 3 , tryptophan-excess diet. Statistical effects: E, energy source; $\mathrm{T}$, tryptophan level; $\mathrm{E} \times \mathrm{T}$, interaction; quad, quadratic effect; lin, linear effect; RSD, residual standard deviation; NS, not significant; $\uparrow P<0 \cdot 10 ;{ }^{*} P<0 \cdot 05$; ${ }^{* *} P<0.01 ; * * * P<0.001$.

$\$$ For details of diets and procedures see Table 1 and pp. 662-665.

Table 6. Effect of dietary energy source and tryptophan level on the mean tissue RNA content ( $\mathrm{mg} / \mathrm{g}$ protein) in various organs of the piglet

\begin{tabular}{|c|c|c|c|c|c|c|c|c|}
\hline \multirow[b]{2}{*}{$\begin{array}{l}\text { Diet ... } \\
n \ldots\end{array}$} & \multirow[b]{2}{*}{$\begin{array}{c}\mathrm{Cl} \\
7\end{array}$} & \multirow[b]{2}{*}{$\begin{array}{c}\mathrm{C} 2 \\
7\end{array}$} & \multirow[b]{2}{*}{$\begin{array}{c}\text { C3 } \\
7\end{array}$} & \multirow[b]{2}{*}{$\begin{array}{c}\mathrm{F} 1 \\
7\end{array}$} & \multirow[b]{2}{*}{$\begin{array}{c}\mathrm{F} 2 \\
6\end{array}$} & \multirow[b]{2}{*}{$\begin{array}{c}\text { F3 } \\
6\end{array}$} & \multicolumn{2}{|c|}{ Statistical significance } \\
\hline & & & & & & & RSD & Effects \\
\hline Jejunal mucosa & $49 \cdot 8$ & $47 \cdot 6$ & $46 \cdot 1$ & $54 \cdot 3$ & $51 \cdot 0$ & $50 \cdot 3$ & $4 \cdot 8$ & $\mathrm{~T}^{*} \operatorname{lin}, \mathrm{E}^{* * *}$ \\
\hline Brain & $15 \cdot 9$ & $15 \cdot 9$ & $16 \cdot 1$ & $15 \cdot 2$ & $15 \cdot 6$ & $15 \cdot 9$ & 0.5 & $\mathrm{E}^{* *}, \mathrm{~T} \dagger \operatorname{lin}$ \\
\hline Semitendinosus & $8 \cdot 2$ & $8 \cdot 1$ & $7 \cdot 4$ & $7 \cdot 3$ & $7 \cdot 0$ & $7 \cdot 5$ & $0 \cdot 6$ & $\mathrm{E} \times \mathrm{T}^{*} \operatorname{lin}$ \\
\hline
\end{tabular}

C, high-carbohydrate diets; F, high-fat diets; 1, tryptophan-deficient diet; 2, tryptophan-adequate diet; 3 , tryptophan-excess diet. Statistical effects: E, energy source; T, tryptophan level; $\mathbf{E} \times \mathbf{T}$, interaction; lin, linear effect; RSD, residual standard deviation; $\nmid P<0 \cdot 10 ;{ }^{*} P<0.05 ;{ }^{* *} P<0.01 ;{ }^{* * *} P<0.001$.

$\ddagger$ For details of diets and procedures see Table 1 and pp. 662-665.

tissue when the TRP level was raised $(P=0.05)$. The same response was not seen in the results for jejunal $k_{s}$; there was in fact a quadratic effect. The RNA concentration of the ST was influenced by an interaction between energy source and TRP $(P=0 \cdot 041)$. Brain tissue RNA was higher with the C diets than with the F diets $(P=0.005)$ and tended to be linearly increased by additional TRP $(P=0.077$; Table 6$)$.

\section{Protein synthesis per unit RNA (RNA activity)}

Liver ribosomal activity was linearly increased by the addition of TRP $(P=0.01)$ to the carbohydrate-rich diet but not to the fat-rich diet. The RNA activity of the ST was linearly increased by TRP addition $(P=0.001)$ while there was a strong trend for a quadratic effect of TRP on LD RNA activity $(P=0.056)$; RNA activity was highest in the TRP-adequate diet group. Whole body RNA activity was increased by TRP addition $(P=0.009$; Table 7$)$. 
Table 7. Effect of dietary energy source and tryptophan level on the mean rates of protein synthesis per unit of $R N A(\mathrm{~g} / \mathrm{g}$ per $d)$ from various tissues of the piglet

\begin{tabular}{|c|c|c|c|c|c|c|c|c|}
\hline \multirow{2}{*}{$\begin{array}{l}\text { Diet ... } \\
n \ldots\end{array}$} & \multirow{2}{*}{$\begin{array}{c}\mathrm{Cl} \\
7\end{array}$} & \multirow{2}{*}{$\begin{array}{c}\mathrm{C} 2 \\
7\end{array}$} & \multirow{2}{*}{$\begin{array}{c}\text { C3 } \\
7\end{array}$} & \multirow{2}{*}{$\begin{array}{c}\mathrm{F} 1 \\
7\end{array}$} & \multirow{2}{*}{$\begin{array}{c}F 2 \\
6\end{array}$} & \multirow{2}{*}{$\begin{array}{c}\text { F3 } \\
6\end{array}$} & \multicolumn{2}{|r|}{ Statistical significance } \\
\hline & & & & & & & RSD & Effects \\
\hline Pancreas & $7 \cdot 2$ & $10 \cdot 2$ & $10 \cdot 6$ & $10 \cdot 5$ & $13 \cdot 4$ & $12 \cdot 9$ & $2 \cdot 4$ & $\mathrm{~T}^{*}$ lin and $\dagger$ quad, $\mathrm{E}^{* * *}$ \\
\hline Duodenal mucosa & $13 \cdot 2$ & $13 \cdot 2$ & $13 \cdot 4$ & $16 \cdot 2$ & $14 \cdot 1$ & $14 \cdot 0$ & 1.9 & $\mathrm{E}^{*}$ \\
\hline Jejunal mucosa & $11 \cdot 2$ & $9 \cdot 7$ & $11 \cdot 1$ & $13 \cdot 5$ & $12 \cdot 2$ & $14 \cdot 1$ & 1.9 & $\mathrm{~T}^{*}$ quad, $\mathrm{E}^{* * *}$ \\
\hline Liver & 16.9 & $18 \cdot 7$ & $21 \cdot 3$ & 18.9 & $21 \cdot 5$ & $19 \cdot 9$ & $2 \cdot 5$ & $\mathrm{~T}^{* *} \operatorname{lin}, \mathrm{E} \times \mathrm{T} \dagger \operatorname{lin}$ \\
\hline Longissimus dorsi & $10 \cdot 4$ & $11 \cdot 2$ & $10 \cdot 7$ & $8 \cdot 0$ & $11 \cdot 4$ & 9.9 & $2 \cdot 2$ & $\mathrm{~T} \dagger$ \\
\hline Semitendinosus & $9 \cdot 6$ & $11 \cdot 4$ & $11 \cdot 9$ & $8 \cdot 7$ & $11 \cdot 7$ & 11.9 & 1.9 & $\mathrm{~T}^{* * *} \operatorname{lin}$ \\
\hline Whole body & $12 \cdot 4$ & $12 \cdot 7$ & $13 \cdot 7$ & $12 \cdot 1$ & $14 \cdot 2$ & $14 \cdot 0$ & $1 \cdot 3$ & $\mathrm{~T}^{* *} \operatorname{lin}$ \\
\hline
\end{tabular}

C, high-carbohydrate diets; F, high-fat diets; 1, tryptophan-deficient diet; 2, tryptophan-adequate diet; 3, tryptophan-excess diet. Statistical effects: E, energy source; T, tryptophan level; quad, quadratic effect; lin, linear effect; RSD, residual standard deviation; $\uparrow P<0 \cdot 10 ; * P<0.05 ; * * P<0.01 ; * * * P<0.001$.

$\ddagger$ For details of diets and procedures see Table 1 and pp. 662-665.

The $\mathrm{F}$ diets augmented the rate of protein synthesis per unit of RNA in the pancreas ( $P$ $=0.0006)$, the mucosa from the duodenum $(P=0.017)$ and jejunum $(P=0.0002)$ when compared with the $\mathrm{C}$ diets (Table 7). There was a significant linear increase in RNA activity in the pancreas $(P=0.004)$ and a trend to a quadratic effect $(P=0.076)$ with the addition of TRP. This indicates that TRP addition positively increased ribosomal activity up to a plateau. TRP addition had a quadratic effect on ribosomal activity $(P=0.022)$ in the mucosa from the jejunum; RNA activity was lowest after the TRP-adequate diets. Brain and femur RNA activities were unaffected by treatment (results not shown).

\section{DISCUSSION}

\section{Growth and blood parameters}

The addition of TRP to a TRP-deficient diet improved growth rate (Cortamira et al. $1991 \mathrm{a}$ ), through an interaction with the energy source. In contrast with the findings of Lewis et al. (1977), TRP had no significant effect on plasma concentrations of urea in the present experiment. The high-fat diets augmented fasting urea levels compared with the high-carbohydrate diets and reduced growth rate, indicating lower $\mathrm{N}$ retention. In contrast to this, Reeds et al. (1987) showed that in the growing pig the addition of fat or carbohydrate to a basal diet was equally effective in reducing urea concentrations, although a period of adaptation was necessary with the addition of fat. Because we used higher levels of fat than Reeds et al. (1987) and lower total energy allowances it is possible that the requirements for glucose were not met by the high-fat diet in the present experiment. In fasting conditions amino acids are used for the synthesis of glucose (Krebs, 1964). Indeed fasting concentrations of gluconeogenic and gluconeogenic/ketogenic amino acids were lower in piglets adapted to the high-fat diets compared with the high-carbohydrate diets (ketogenic amino acids were not affected). Therefore, increased glucose synthesis from amino acids may explain in part the higher urea concentrations and lower growth rates seen after the high-fat diets. In agreement with previous work (Ponter et al. 1991 a), highcarbohydrate diets induced higher systemic plasma insulin and GIP concentrations than high-fat diets. These responses are consistent with the physiological roles for these 
hormones, since insulin and GIP (through its insulinotropic action) act to re-establish glucose homeostasis after a meal.

The present experiment did not confirm the stimulatory effect of dietary tryptophan on insulin concentrations, as previously seen in the rat (Tsiolakis \& Marks, 1984) and in the piglet (Cortamira et al. 1991 a). Indeed, there was a trend for insulin concentrations to be higher in the TRP-deficient group of piglets than the TRP-adequate group.

It has been known for some time that TRP increases the activity of liver amino acid degrading enzymes (Kaplan \& Pitot, 1970). If in the case of TRP deficiency the activity of these enzymes was not adequate there could be an accumulation of amino acids in the blood. Amino acids could also accumulate as a result of reduced utilization for net protein synthesis in TRP-deficient conditions. However, the amino acids likely to stimulate insulin secretion, leucine, lysine and arginine (Gerich et al. 1976), were not affected by TRP in the present experiment (results not shown).

A positive linear relationship between TRP and insulin was not found in the present experiment. This is probably related to the extreme diets used (fat:carbohydrate ratio). In addition to this, TRP has many physiological actions not directly linked to its insulinliberating ability. TRP has been implicated in gastric emptying (Stephens et al. 1975), feed intake and diet selection, possibly through serotonin (Forbes \& Blundell, 1989), and the clearance of glucose from the blood (Wittman, 1975). Indeed, we have shown in the same experiment that plasma insulin and glucose concentrations were higher after an oral glucose load in piglets adapted to TRP-deficient diets compared with TRP-adequate and -excess diets (Ponter et al. 1991 b), indicating insulin resistance. In the present conditions adaptation to the experimental diets may have had long-term influences, the most important being the induction of insulin resistance in TRP-deficient conditions.

As expected, increasing the level of dietary TRP augmented the plasma concentrations of TRP both in the fasted and fed (values not shown) states (Sève et al. 1991). In the fasted state the concentrations of the majority of amino acids were lower on diet F compared with C, but not so for TRP. In TRP-deficient conditions the reutilization and oxidation of TRP returning from protein degradation may be inhibited in piglets receiving the high-fat diets (see Fig. 2). The growth data indicate that the TRP deficiency was more acute in the piglets given the $\mathrm{F}$ diets. These findings may be explained by a reduction in the reutilization of TRP for protein synthesis because other amino acids became limiting. This may result from the use of glucose-forming amino acids for gluconeogenesis in animals receiving the highfat diets.

\section{Protein synthesis}

The use of the 'flooding dose' method to measure protein synthesis in the intestine has been validated previously using leucine (McNurlan et al. 1979) and phenylalanine (Sève et al. 1986; Southorn et al. 1992). The present experiment showed that the replacement of carbohydrate in the diet by fat, on an energy basis, augmented the rate of protein synthesis in some digestive tissues and this was associated with increased RNA activity. The adaptation of pancreatic enzyme synthesis due to diet modification may explain differences in $k_{s}$. High-carbohydrate diets induce an augmentation of amylase (EC 3.2.1.1) content and synthesis, while high-fat diets have a similar effect on lipase (EC 3.1.1.3) in the pancreas (Wicker \& Puigserver, 1987). Wicker \& Puigserver (1989) have also shown that a high-fat diet increases total protein synthesis in the pancreas when using labelled methionine. Previous findings have shown that protein quality is important in the pancreatic enzyme adaptation to diet (Johnson et al. 1977). They showed that increasing the dietary content of a low quality protein did not increase pancreatic proteases. However, when the levels of the two limiting amino acids (tryptophan and lysine) were also 
augmented, protease adaptation did occur. The results of the present experiment indicate that at the levels of TRP used pancreatic $k_{s}$ was approaching a maximum value with the TRP-excess diets.

High-fat diets have trophic effects on the intestine of rats. Maxton et al. (1989) showed that small intestine weight, mucosal weight, protein and DNA content were increased by a high-fat diet. In addition, Pell et al. (1992) showed that crypt-cell production rate was increased by a high-fat diet. Efficient absorption and transport of fatty acids necessitates the synthesis of chylomicron proteins and this may need to be increased after the $F$ diets to permit efficient fat absorption.

Attaix et al. (1988) concluded from experiments comparing fed and fasted rats that intestinal protein synthesis was relatively resistant to fasting and McNurlan et al. (1979) showed that fasting had no effect on intestinal $k_{s}$ or RNA concentration in rats. In the present experiment we found that the most unexpected effect in both the duodenal and the jejunal mucosa was that $k_{s}$ was increased under TRP-deficient compared with TRPadequate conditions in response to the high-fat diets compared with the high-carbohydrate diets. The present findings together with those of McNurlan et al. (1979) and Attaix (1988) suggest that there may be a protective mechanism in the mucosa which maintains the functional activity of the intestine under non-optimal nutritional conditions such as fasting and essential amino acid imbalance.

We showed that the substitution of carbohydrate for fat (which increased plasma insulin concentrations) significantly enhanced $k_{s}$ in the skin and that this was accompanied by a trend to an increase in LD protein synthesis rate. Therefore, we were not able to show unequivocally that there was a positive relationship between plasma insulin and $k_{s}$ (Garlick \& Lobley, 1987). Our results are consistent with those of Reeds et al. (1987) who showed that the addition of fat or carbohydrate to a basal diet was equally effective in stimulating protein synthesis once a period of adaptation had taken place. A possible reason for the difference between the experimental results of Garlick \& Lobley (1987), and those of Reeds et al. (1987) and the present study is the method used to manipulate insulin. In experiments where insulin stimulated $k_{s}$, insulin or an insulin-releasing nutrient was infused intravenously. In the present experiment insulin was manipulated through the diet and this could cause long-term changes in the mechanisms that control growth and metabolism. In addition, adaptation to high-fat diets can cause the development of tissue insulin resistance in certain tissues. For example, insulin receptor number and affinity on adipocytes and hepatocytes are reduced by high-fat diets (Sun et al. 1977: Olefsky \& Saekow, 1978) and there are post-receptor defects. High-carbohydrate diets also reduce insulin receptor number but the ability of insulin to promote glucose transport and metabolism is improved (Olefsky \& Saekow, 1978). Therefore, plasma insulin concentrations may not reflect accurately insulin action.

In the present experiment the rate of protein synthesis in the LD was affected quadratically while that in the ST was affected linearly by increasing TRP. This may be due to a difference in the TRP requirement between muscles, reflecting different proportions of cell types and, as a result, differences in amino acid composition and metabolism. The function of a muscle, for example postural (ST) compared with non-postural (LD), may be important in deciding its sensitivity to nutritional stress (Lefaucheur, 1990).

Globally, liver $k_{s}$ and RNA activity were linearly increased by TRP addition, while RNA capacity was not affected (Cortamira et al. 1991a). However, the trend to an interaction between energy source and TRP indicates that it was only with the carbohydrate-rich diets that TRP addition linearly increased $k_{s}$. At the highest TRP level pigs given the high-fat diet were not capable of a further increase in $k_{s}$. This may be related to a change in liver metabolism in response to high-fat diets, possibly through insulin. 
Brain $k_{s}$ was measured because the brain uses exclusively glucose rather than fatty acids for energy metabolism; therefore the substitution of carbohydrate in the diet by fat may be expected to have an effect on $k_{s}$. However, this was not the case. Brain $k_{s}$ and RNA activity were relatively resistant to dietary manipulation, in spite of the competition between the branched chain amino acids and TRP for uptake across the blood-brain barrier (Fernstrom \& Wurtman, 1972) which may reduce the supply of TRP (in TRP-deficient conditions) to a relatively greater extent than in other tissues. These results agree with the established view that brain metabolism is protected.

Whole body $k_{s}$ was linearly increased by the addition of TRP, and this was mediated by an augmentation in RNA activity (Cortamira et al. 1991 a). There was no effect of energy source on whole body $k_{s}$ which is in agreement with the findings of Reeds et al. (1987). Jepson et al. (1988) have concluded from experiments with rats that $k_{s}$ is more sensitive to the stimulatory action of insulin at low concentrations. However, this may not be the case in meal-fed animals such as the pig where insulin concentrations rise to relatively high levels compared with rats which do not meal-feed.

The present results suggest that in undernourished early-weaned piglets growth performance is limited by insufficient glucose supply associated with tryptophan deficiency. The effect of TRP deficiency on insulin secretion may have been masked by an effect on insulin sensitivity or glucose tolerance. We were able to confirm the stimulatory effects of dietary TRP on $k_{s}$ in various tissues of the piglet. In general, energy source had little effect on $k_{s}$ in structural tissues although $k_{s}$ in digestive tissues was positively stimulated by fatrich diets. We could not confirm a positive relationship between plasma insulin and $k_{s}$ when insulin was manipulated through the energy source of the diet. As a result of dietary manipulation and the possible adaptation of insulin-mediated metabolism, plasma insulin levels may not reflect accurately insulin action.

A.A.P. would like to acknowledge the financial support of the AFRC Institute of Grassland and Environmental Research and the INRA Station de Recherches Porcines during this experiment. The authors would like to thank Y. Lebreton for performing the surgery, Y. Colléaux for the plasma amino acid analysis, P. Ganier for technical assistance and $\mathbf{R}$. Levrel for care of the animals.

\section{REFERENCES}

Attaix, D. (1988). The influence of age and weaning on protein synthesis in the lamb. PhD Thesis, University Blaise Pascal, Clermont Ferrand.

Brown, J. C. (1974). "Enterogastrone" and other new gut peptides. Medical Clinics of North America 58, 1347-1358.

Cortamira, N. O., Sève, B., Lebreton, Y. \& Ganier, P. (1991 a). Effect of dietary tryptophan on muscle, liver and whole-body protein synthesis in weaned piglets: relationship to plasma insulin. British Journal of Nutrition 66 , $423-435$.

Cortamira, O., Sève, B., Ponter. A. \& Salter, D. N. (1991 b). The effect of dietary energy source and level of tryptophan on growth and protein synthesis in different tissues of early-weaned piglets. Proceedings of the 6th International Symposium on Protein and Nutrition, Herning, Denmark, pp. 122-124.

Fernstrom, J. D. \& Wurtman, R. J. (1972). Brain serotonin content : physiological regulation by plasma neutral amino acids. Science 178, 414416.

Forbes, J. M. \& Blundell, J. E. (1989). Central control of voluntary feed intake. In The Voluntary Food Intake of Pigs. Occasional publication No. 13, British Society of Animal Production, pp. 7-26 [J. M. Forbes, M. A. Varley and T. L. J. Lawrence, editors]. Haddington: D. and J. Croal Ltd.

Garlick, P. J. \& Lobley, G. E. (1987). Dietary intake and protein turnover. In Protein Metabolism and Nutrition, European Association for Animal Production Publication no. 35, pp. 13-21 [J. Lehman, editor]. Rostock: Wilhem-Pieck-Universitat.

Gerich, J. E., Charles, M. A. \& Grodsky, G. M. (1976). Regulation of pancreatic insulin and glucagon secretion. Annual Review of Physiology 38, 353-388.

Institut National de la Recherche Agronomique (1989). L'alimentation des animaux monogastriques, porc, lapin, 
volailles (The nutrition of simple-stomached animals: pig, rabbit, fowl), 2nd ed. Paris: Institut National de la Recherche Agronomique.

Jefferson, L. S. (1980). Role of insulin in the regulation of protein synthesis. Diabetes 29, 487-496.

Jepson, M. M., Bates, P. C. \& Millward, D. J. (1988). The role of insulin and thyroid hormones in the regulation of muscle growth and protein turnover in response to dietary protein in the rat. British Journal of Nutrition $\mathbf{5 9}$, $397-415$.

Johnson, A., Hurwitz, R. \& Kretchmer, N. (1977). Adaptation of rat pancreatic amylase and chymotrypsinogen to changes in diet. Journal of Nutrition 107, 87-96.

Kaplan, J. H. \& Pitot, H. C. (1970). The regulation of intermediary amino acid metabolism in animal tissues. In Mammalian Protein Metabolism, vol. IV, pp. 387-443 [H. N. Munro, editor]. New York and London: Academic Press.

Krebs, H. A. (1964). The metabolic fate of amino acids. In Mammalian Protein Metabolism, vol. I, pp. 125-177 [H. N. Munro and J. B. Allison, editors]. New York and London: Academic Press.

Lefaucheur, L. (1990). Changes in muscle fiber populations and muscle enzyme activities in the primiparous lactating sow. Reproduction Nutrition Développement 30, 523-531.

Lewis, A. J., Peo, E. R., Cunningham, P. J. \& Moser, B. D. (1977). Determination of the optimum dietary proportions of lysine and tryptophan for growing pigs based on growth, food intake and plasma metabolites. Journal of Nutrition 107, 1369-1376.

McNurlan, M. A., Tomkins, A. M. \& Garlick, P. J. (1979). The effect of starvation on the rate of protein synthesis in rat liver and small intestine. Biochemical Journal 178, 373-379.

McPhate, G. F. (1986). The effect of ingestion of single amino acids on glucoregulatory hormones in man. MSc Thesis, University of Surrey.

Maxton, D. G., Cynk, E. U., Jenkins, A. P. \& Thompson, R. P. H. (1989). Effect of dietary fat on the small intestine. Gut 30, 1252-1255.

Morgan, L. M., Morris, B. A. \& Marks, V. (1978). Radioimmunoassay of gastric inhibitory polypeptide. Annals of Clinical Biochemistry 15, 175-177.

Olefsky, J. M. \& Saekow, M. (1978). The effects of dietary carbohydrate content on insulin binding and glucose metabolism by isolated rat adipocytes. Endocrinology 103, 2252-2263.

Pell, J. D., Gee, J. M., Wortley, G. M. \& Johnson, I. T. (1992). Dietary corn oil and guar gum stimulate intestinal crypt proliferation in rats by independent but potentially synergistic mechanisms. Journal of Nutrition 122 , 2447-2456.

Ponter, A. A., Salter, D. N., Morgan, L. M. \& Flatt, P. R. (199l $a$ ). The effect of energy source and feeding level on the hormones of the entero-insular axis, and plasma glucose in the growing pig. British Journal of Nutrition 66, 187-197.

Ponter, A. A., Sève, B., Cortamira, N. O., Salter, D. N. \& Morgan, L. M. (1991 b). The effects of energy source and tryptophan level on hormones of the entero-insular axis and glucose in the early weaned pig after an intragastric infusion of glucose. Proceedings of the Nutrition Society 50, 227A.

Reeds, P. J., Fuller, M. F., Cadenhead, A. \& Hay, S. M. (1987). Urea synthesis and leucine turnover in growing pigs: changes during $2 \mathrm{~d}$ following the addition of carbohydrate or fat to the diet. British Journal of Nutrition 58, 301-311.

Reeds, P. J., Fuller, M. F., Cadenhead, A., Lobley, G. E. \& McDonald, J. D. (1981). Effects of changes in the intakes of protein and non-protein energy on whole-body protein turnover in growing pigs. British Journal of Nutrition 45, 539-546.

Ross, G. J. S. (1980). Maximum Likelihood Programme (MLP). Rothamstead: Rothamstead Experimental Station.

Sève, B., Meunier-Salaün, M. C., Monnier, M., Colléaux, Y. \& Henry, Y. (1991). Impact of dietary tryptophan and behaviour type on growth performance and plasma amino acids of young pigs. Journal of Animal Science 69, 3679-3688

Sève, B., Reeds, P. J., Fuller, M. F., Cadenhead, A. \& Hay, S. M. (1986). Protein synthesis and retention in some tissues of the young pig as influenced by dictary protein intake after early weaning. Possible connection to the energy metabolism. Reproduction Nutrition Développement 26, 849-861.

Sidransky, H., Verney, E. \& Sarma, D. S. R. (1971). Effect of tryptophan on polyribosomes and protein synthesis in liver, American Journal of Clinical Nutrition 24, 779-785.

Southorn, B. G., Kelly, J. M. \& McBride, B. W. (1992). Phenylalanine flooding dose procedure is effective in measuring intestinal and liver protein synthesis in sheep. Journal of Nutrition 122, 2398-2407.

Statistical Analysis Systems Institute Inc. (1989). SAS/STST User's Guide, Release 6.03. Cary, NC: SAS Institute Inc.

Stephens, J. R., Woolson, R. F. \& Cooke, A. R. (1975). Effects of essential and non essential amino acids on gastric emptying in the dog. Gastroenterology 69, 920-927.

Sun, J. V., Tepperman, H. M. \& Tepperman, J. (1977). A comparison of insulin binding by liver plasma membranes of rats fed a high glucose diet or a high fat diet. Journal of Lipid Research 18, 533-539.

Sykes, S., Morgan, L. M., English, J. \& Marks, V. (1980). Evidence for preferential stimulation of GIP secretion in the rat by actively transported carbohydrates and their analogues. Journal of Endocrinology 85, $201-207$.

Thomas, F. B., Sinar, D., Mazzerferri, E. L., Cataland, S., Mekjian, H. S., Caldwell, J. H. \& Fromkes, J. J. (1978). 
Selective release of gastric inhibitory polypeptide by intraduodenal amino acid perfusion in man. Gastroenterology 74, 1261-1265.

Tsiolakis, D. \& Marks, V. (1984). The differential effect of intragastric and intravenous tryptophan on plasma glucose, insulin, glucagon and GIP in the fasted rat. Hormone and Metabolic Research 16, 226-229.

Vesely, J. \& Cihak, A. (1970). Enhanced DNA-dependent RNA polymerase and RNA synthesis in rat liver nuclei after administration of L-tryptophan. Biochimica et Biophysica Acta 204, 614-616.

Wicker, C. \& Puigserver, A. (1987). Effects of inverse changes in dietary lipid and carbohydrate on the synthesis of some pancreatic secretory proteins. European Journal of Biochemistry 162, 25-30.

Wicker, C. \& Puigserver, A. (1989). Changes in mRNA levels of rat pancreatic lipase in the early days of consumption of a high-lipid diet. European Journal of Biochemistry 180, 563-567.

Wittman, J. S. (1975). Alteration of glucose tolerance by dietary L-tryptophan in rats. Journal of Nutrition $\mathbf{1 0 6}$, $631-635$. 